\title{
Colour Responses of Two Fast-growing Hardwoods to Two-step Steam-heat Treatments
}

\author{
Pedro Henrique G. de Cademartori ${ }^{\mathrm{a} *}$, Bruno D. Mattos ${ }^{\mathrm{b}}$, André L. Missio ${ }^{\mathrm{c}}$, Darci A. Gatto ${ }^{\mathrm{c}, \mathrm{d}}$ \\ ${ }^{a}$ Wood and Forestry Science Centre - PPGEF, Federal University of Paraná - UFPR, \\ Av. Prefeito Lothário Meissner, 900, CEP 80210-170, Curitiba, PR, Brazil \\ ${ }^{\mathrm{b}}$ College of Materials Science \& Engineering (PIPE), Federal University of Paraná - UFPR, \\ Polytechnic Center, CP 19011, CEP 81531-990, Curitiba, PR, Brazil \\ ${ }^{c}$ Forestry Engineering - PPGEF, Forest Products Laboratory, Centre of Rural Sciences, \\ Federal University of Santa Maria - UFSM, CP 221, CEP 97105-900, Santa Maria, RS, Brazil \\ ${ }^{d}$ College of Materials Engineering (PPGCEM), Federal University of Pelotas, \\ R. Félix da Cunha 809, CEP 96010-000, Pelotas, RS, Brazil
}

Received: June 30, 2013; Revised: January 15, 2014

\begin{abstract}
Colour changes by thermal treatments are a good alternative to increase wood quality, especially for non-structural uses. In this study, rose gum (Eucalyptus grandis) and Sydney blue gum (Eucalyptus saligna) woods from Southern Brazil were thermally treated under different conditions (steam pretreatment in an autoclave at $127^{\circ} \mathrm{C}$ for 1 hour and heat treatment in an oven at 180, 200, 200 and $240{ }^{\circ} \mathrm{C}$ for 4 hours) and colour changes were investigated using CIE $L * a * b *$ technique. The main findings show that thermal treatments resulted in darkening of the wood, which was more intense at high temperatures. Colour difference after two-step steam-heat treatments was higher than 45 for both species. In general, the influence of the steam pre-treatment was more visible in lower temperatures. Lightness $\left(L^{*}\right)$ was the parameter that best described the colorimetric behaviour of rose gum and Sydney blue gum woods. In conclusion, thermal treatments are a great method to improve the market value of wood, especially for aesthetic uses, but it requires a control of process conditions.
\end{abstract}

Keywords: $C I E-L * a * b *$ technique, thermal treatment, colorimetry, wood technology

\section{Introduction}

Thermal treatment is an eco-friendly wood treatment process that aims to expose wood at temperatures higher than $180^{\circ} \mathrm{C}$. This process mainly entails increasing the durability and dimensional stability of wood pieces and has become an important niche in the wood market of some European and North American countries ${ }^{1,2}$. Nevertheless, the thermal treatment causes weight loss and, consequently, a decrease in mechanical strength ${ }^{3}$, which limits the structural use of thermally treated wood. All the changes on wood properties depend to the process conditions, in which can be performed mainly only heating ${ }^{2}$, only steam ${ }^{4}$ or a combination of steam and heating ${ }^{5}$.

Wood colour modification by thermal treatment is possible and can be worthwhile primarily when the material is chosen based on aesthetic and non-structural factors. According to Todorovic et al. ${ }^{6}$, thermal treatment enables many uses and increases the market value of less-valued species.

Colorimetric changes by thermal treatment are characterised by a homogeneous darkening of the wood surface ${ }^{7}$ and occur due to the modifications in the chemical structure of wood, mainly related to a decrease in hemicelluloses content, condensation and migration of extractives to the wood surface. Therefore, chemical changes are widely related to the process conditions such as temperature, time of exposure and atmosphere.

Measurement of colorimetric changes is essentially performed through an efficient technique regularised by

*e-mail: pedrocademartori@gmail.com
CIE (Commission International de L'Éclairage), in which some parameters are measured: lightness $\left(L^{*}\right)$, chromaticity coordinates $\left(a^{*}\right.$ and $\left.b^{*}\right)$, chroma $\left(C^{*}\right)$ and hue angle $(h)^{6}$. As such, the influence of thermal treatment in the wood colour could be determined just as reported in other studies ${ }^{8-11}$.

Wood colour vary according to its origin and is an important factor when the material is in service. Amongst the eucalypt species, rose gum wood is considered one of the most valued cabinet timbers (e.g. production of veneered panels, joinery, plywood and furniture), while Sydney blue gum wood has been used in the Australian market for the production of flooring, shipbuilding and general building and construction work ${ }^{12}$.

In many aforementioned cases, colorimetric changes are a good alternative to increase wood quality. Therefore, the control of wood colour is an important parameter for identification, utilisation and determination of its market value considering aesthetic factors ${ }^{13}$.

In this context, this study aimed to characterise the colorimetric changes in rose gum and Sydney blue gum woods thermally treated under different process conditions.

\section{Material and Methods}

\subsection{Raw materials}

Six rose gum and Sydney blue gum trees were randomly selected from a fast-growing population located on the north 
coast of Rio Grande Sul state, Southern Brazil (30 $14^{\circ}$ 09.73', S, 50 19' 55.07' W).

Two hundred and seventy samples (15 samples per treatment) measuring $16 \times 16 \times 250 \mathrm{~mm}$ (radial $\times$ tangential $\times$ longitudinal) were prepared from the first $\log (3.15 \mathrm{~m}$ length) of each tree. The samples were prepared only with straight grain, heartwood and absence of flaws. The samples were conditioned in a climatic chamber $\left(20^{\circ} \mathrm{C}\right.$ and $65 \%$ of relative humidity) in order to stabilise the equilibrium moisture content $(\sim 12 \%)$, which was the initial point of the thermal treatments.

\subsection{Two-step steam-heat treatments}

Eight two-step steam-heat treatments were performed in rose gum and Sydney blue gum woods (Table 1). The untreated samples (control treatment) were kept in a climatic chamber $\left(20^{\circ} \mathrm{C}\right.$ and $65 \%$ of relative humidity) the entire time.

One hundred and twenty samples were modified using combined steam pre-treatment in an autoclave and heat treatment in an oven. To achieve this, a steam pretreatment in the autoclave at $127^{\circ} \mathrm{C}$ and $1.5 \mathrm{kgf} / \mathrm{cm}^{2}$ for 1 hour was performed. Pre-treated samples were conditioned in a climatic chamber for stabilisation of the equilibrium moisture content. Thus, these samples were treated in an oven (heating rating $2{ }^{\circ} \mathrm{C} / \mathrm{min}$ ) without force air circulation at $180,200,220$ and $240{ }^{\circ} \mathrm{C}$ for 4 hours after reaching the temperature of treatment.

Another one hundred and twenty samples were treated only in an oven (heating rating $2{ }^{\circ} \mathrm{C} / \mathrm{min}$ ) without force air circulation at $180,200,220$ and $240{ }^{\circ} \mathrm{C}$ for 4 hours after reaching the temperature of treatment. All the samples were kept in a climatic chamber $\left(20^{\circ} \mathrm{C}\right.$ and $65 \%$ of relative humidity) in order to stabilise the equilibrium moisture content for the colorimetric evaluation.

\subsection{Colorimetric evaluation}

The colorimetric evaluation was performed using a colorimeter (Konica Minolta CR-400), which was set for D65 light source and $10^{\circ}$ of observation angle as described by Commission Internationale de L'éclairage (CIE- $L * a * b *$ standard).

Three measurements were performed in both radial and tangential directions for each sample (six measurements per sample). Thus, the colorimetric parameters $L *$ (lightness), $a^{*}$ (green-red chromatic coordinate) and $b^{*}$ (blue-yellow chromatic coordinate) were obtained. The parameters $\Delta \mathrm{E}$ (colour difference), $C^{*}$, (chroma) and $h$ (hue angle) and $\Delta \mathrm{E}$ (colour difference) were measured using Equations 1, 2 and 3 , respectively.

$$
\begin{aligned}
& \Delta E=\left(\Delta L^{* 2}+\Delta a^{* 2}+\Delta b^{* 2}\right)^{1 / 2} \\
& C^{*}=\left(a^{* 2}+b^{* 2}\right)^{1 / 2} \\
& h=\operatorname{tang}^{-1}\left(\frac{b^{*}}{a^{*}}\right)
\end{aligned}
$$

$\Delta E=$ colour difference; $\Delta L^{*}, \Delta a^{*} e \Delta b^{*}=$ variation of lightness, green-red chromatic coordinate and blue-yellow chromatic coordinate for untreated and thermally treated samples; $C^{*}=$ chroma; $h=$ hue angle; $a^{*}=$ greenred chromatic coordinate; $b^{*}=$ blue-yellow chromatic coordinate.

\subsection{Statistical analysis}

The collected data was analysed using descriptive statistic and factorial analysis of variance $(p<0.05)$ with a factorial scheme $2 \times 4+1$, i.e, use or not of steam pretreatment in autoclave and four temperatures in oven with an additional treatment (control), respectively. The average values were compared with Tukey Test at a level of significance of $5 \%$. Moreover, the data was analysed through $L^{*}$ x $C^{*}$ diagrams as described by Konica Minolta ${ }^{14}$ and Mattos et al. ${ }^{15}$ in order to better elucidate the colorimetric changes after the application of the thermal treatments.

\section{Results and Discussion}

The darkening of treated samples for both species in radial and tangential directions was observed through visual analysis (Figure 1). The darkening of samples was gradual and occurred as a function of the temperature of treatment. The highest darkening for both species was observed in the most drastic treatments (8 and 9). Quantity and properties of extractives composition and major chemicals components in wood are modified due to the application of steamheat treatments ${ }^{16}$. Formation of aldehydes and phenols are observed if wood is exposed at high temperatures.

Table 1. Two-step steam-heat treatments performed in rose gum and Sydney blue gum woods.

\begin{tabular}{ccccc}
\hline Treatment & Steam pre-treatment in autoclave $\left({ }^{\circ} \mathbf{C}\right)$ & Pre-treatment time $(\mathbf{h})$ & Heating Temperature $\left({ }^{\circ} \mathbf{C}\right)$ & Heating Time $(\mathbf{h})$ \\
\hline 1 (Control) & - & - & - & - \\
2 & - & - & 180 & 4 \\
3 & 127 & 1 & 180 & 4 \\
4 & - & - & 200 & 4 \\
5 & 127 & 1 & 200 & 4 \\
6 & - & - & 220 & 4 \\
7 & 127 & 1 & 220 & 4 \\
8 & - & - & 240 & 4 \\
9 & 127 & 1 & 240 & 4 \\
\hline
\end{tabular}


Consequently, coloured compounds are formed after chemical reactions ${ }^{17}$.

As can be seen in Table 2, steam pre-treatment in the autoclave, the temperature of heat treatment and its interactions significantly influenced the parameters $L^{*}, a^{*}$ and $b^{*}$ of rose gum and Sydney blue gum wood in both radial and tangential directions. The contrast of thermal treatments (factorial) vs. control treatment (untreated samples) was significant for all colorimetric parameters for both species and anatomical directions, except for $a^{*}$ in tangential direction of Sydney blue gum wood.

In general, the average values of $L^{*}, a^{*}$ and $b^{*}$ presented an inverse behaviour in relation to the temperature of exposure (Figure 2), which was also observed by other studies $^{18,19,20}$.

Changes in $L^{*}$ for both species showed a high and significant decrease after treatment 2 in radial and tangential directions, whilst a stabilisation from treatment 6 was observed (Figure 2). Moreover, considering the same temperature, $L^{*}$ of steam pre-treated rose gum wood higher decreased than $L^{*}$ of wood treated only in the oven. That occurred mainly in the treatment at $180{ }^{\circ} \mathrm{C}$ because the application of higher temperatures reduced the influence of steam pre-treatment on wood colour, for which a stabilisation of $L *$ between treatments with the same level of temperature in the oven was observed. Bekhta and Niemz ${ }^{8}$ reported that levels of $L^{*}$ of Norway spruce wood decreased significantly only after thermal treatment at $200{ }^{\circ} \mathrm{C}$.

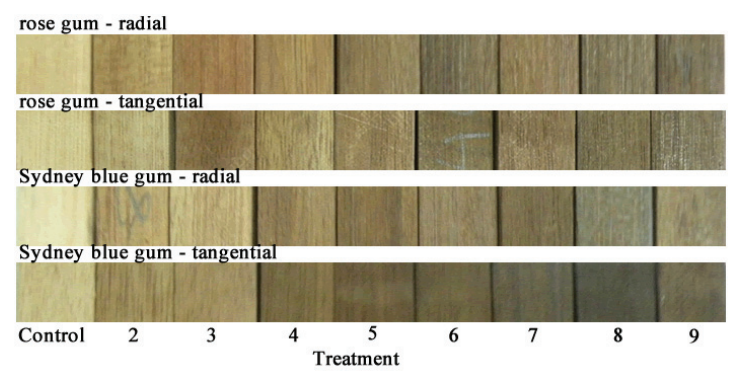

Figure 1. Visual evaluation of untreated and thermally treated wood samples.
Decrease in lightness is related to the extractives content and low molecular weight compounds ${ }^{21}$, and to the degradation of hemicelluloses, mainly pentose ${ }^{22}$. Moreover, increase of lignin content due to the exposure at high temperatures contributes for darkening of wood ${ }^{23}$.

The highest reductions in $L^{*}$ were observed for treatments 8 and 9 , in which the highest variations occurred in Sydney blue gum wood: $61.26 \%$ in radial direction and $61.66 \%$ in tangential direction. Therefore, according to the results verified for $L^{*}$, level of lightness intensity is widely related to the processing of wood at high temperatures. Likewise, Wiberg ${ }^{24}$ stated that $L^{*}$ was the most affected colorimetric parameter by the time and the temperature of drying when compared to other parameters.

Polyphenols content shows a high positive correlation with the wood colour. The red tones increase with an increase of polyphenols content and, consequently, the wood samples are darker ${ }^{25}$.

Parameter $a^{*}$ of rose gum and Sydney blue gum wood showed similar behaviour as a function of the heating temperature of exposure. As observed in Figure 1, $a^{*}$ increased after thermal treatments 2 and 3 and then decreased until the highest heating temperature applied. According to Chen et al. ${ }^{26}$, increase of $a^{*}$ is related to the condensation, degradation and oxidation of many wood elements. The authors affirmed that substances such as lignin, proanthocyanidins and other extractives could condense and form by-products and, consequently, contribute to the increase of red tone intensity on the wood sample.

Sydney blue gum wood showed values of $a^{*}$ slightly lower than rose gum wood, which confirms its less natural intensity of red tones. The highest decrease of $a *$ in relation to the treatment 1 (control) was verified for Sydney blue gum wood, which was $29.26 \%$ in the radial direction and $32.41 \%$ in the tangential direction. Varga and Van der Zee ${ }^{27}$ observed that colour changes by steaming highly depend to the wood species used.

Schnabel et al. ${ }^{28}$ observed the same behaviour of $a^{*}$ for European ash and European beech wood, in which that parameter increased after treatment with low intensity and decreased when treated at high temperatures. Likewise, Bekhta and Niemz ${ }^{9}$ reported an increase of $a^{*}$ of Norway

Table 2. Summary of factorial analysis of variance with additional treatment for the parameters $L^{*}, a^{*}$ and $b^{*}$ in radial and tangential direction of rose gum and Sydney blue gum woods.

\begin{tabular}{|c|c|c|c|c|c|c|c|}
\hline & & \multicolumn{6}{|c|}{ F-value } \\
\hline & & \multicolumn{3}{|c|}{ Radial } & \multicolumn{3}{|c|}{ Tangential } \\
\hline & & $L^{*}$ & $a^{*}$ & $b^{*}$ & $L^{*}$ & $a^{*}$ & $b^{*}$ \\
\hline \multirow[t]{4}{*}{ Rose gum } & Pre-treatment (A) & $27.67 *$ & $534.94 *$ & $142.34 *$ & $144.69 *$ & $138.66^{*}$ & $177.51^{*}$ \\
\hline & Temperature (B) & $1283.05^{*}$ & $15.07^{*}$ & $267.19 *$ & $1080.63 *$ & $78.97^{*}$ & $165.67 *$ \\
\hline & A vs. B & $295.63 *$ & $512.42 *$ & $40.31 *$ & $280.28^{*}$ & $205.38 *$ & $42.50 *$ \\
\hline & Fact. vs. Control & $4963.27 *$ & $317.10^{*}$ & $241.18 *$ & $3909.79 *$ & $127.10^{*}$ & $176.94 *$ \\
\hline \multirow[t]{4}{*}{ S. blue gum } & Pre-treatment (A) & $250.54 *$ & $1735.49 *$ & $645.21 *$ & $45.49 *$ & $52.77 *$ & $174.32 *$ \\
\hline & Temperature (B) & $1890.30^{*}$ & $50.66^{*}$ & $406.10 *$ & $850.43^{*}$ & $467.66^{*}$ & $583.08 *$ \\
\hline & A vs. B & $327.50^{*}$ & $528.38 *$ & $124.75 *$ & $80.60^{*}$ & $108.88 *$ & $96.45 *$ \\
\hline & Fact. vs. Control & $8332.32 *$ & $225.84 *$ & $661.52 *$ & $6970.37 *$ & $1.25^{\mathrm{ns}}$ & $696.80 *$ \\
\hline
\end{tabular}

* Significant at $1 \%$ of probability of error; ${ }^{\text {ns }}=$ not significant; Fact= Factorial; Control= Control treatment (untreated samples). 

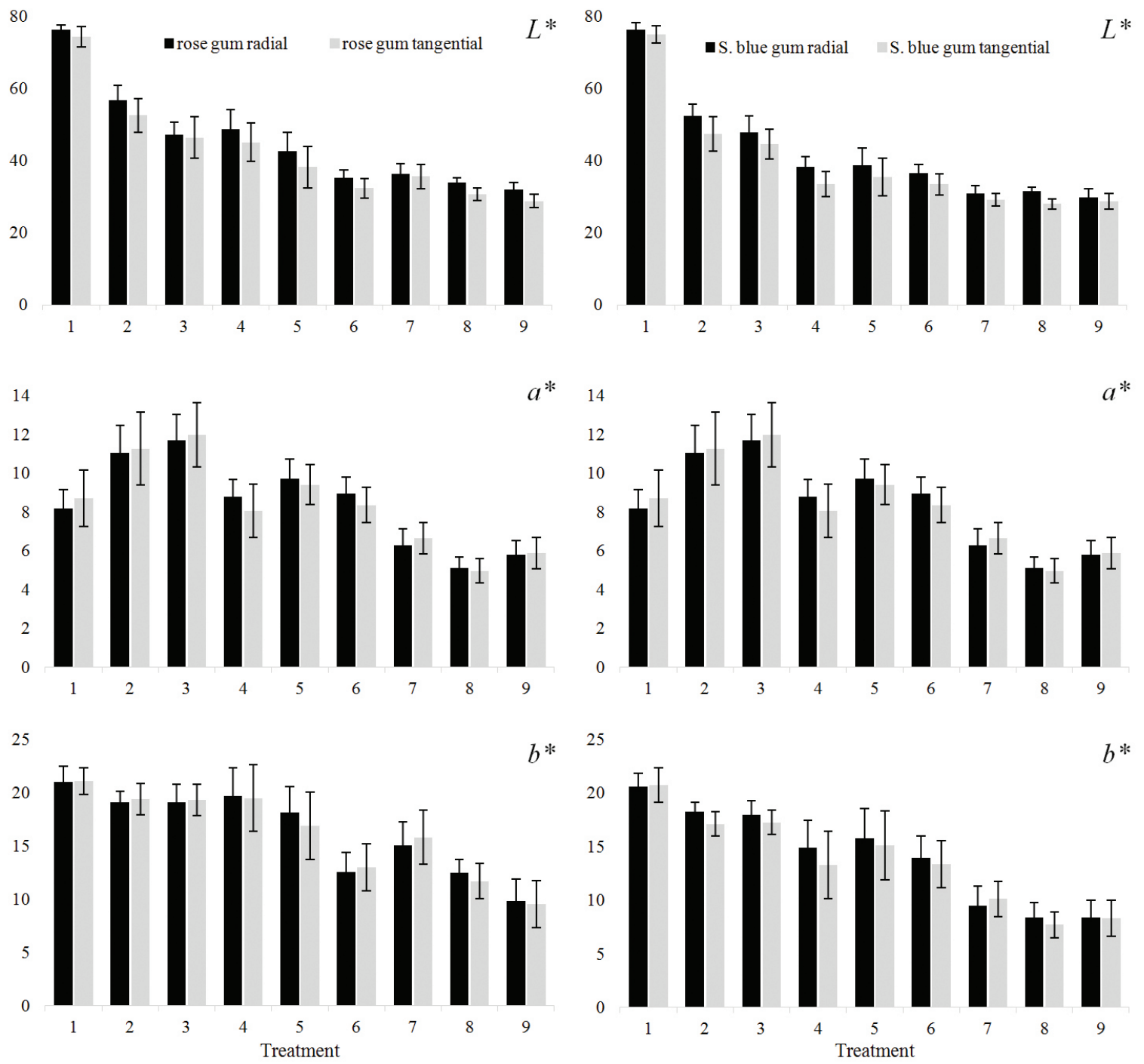

Figure 2. Average values of parameters $L^{*}, a^{*}$ and $b^{*}$ in radial and tangential direction of rose gum and Sydney blue gum untreated and thermally treated woods.

spruce wood by 4.4 times after treatment at $200{ }^{\circ} \mathrm{C}$ when compared to the treatment at $150{ }^{\circ} \mathrm{C}$.

The application of treatment $2\left(180^{\circ} \mathrm{C}\right)$ was sufficient to significantly reduce the yellow tone of wood samples in both directions and species. However, changes in $b^{*}$ were less intense than changes in lightness $\left(L^{*}\right)$.

These observations show a high tendency of reduction of yellow tone, which is naturally presented in untreated wood samples. According to Mori et al. ${ }^{25}, b^{*}$ in eucalypt wood is significantly influenced by the soluble lignin, polyphenols content and fibre length.

As observed in Table 3, steam pre-treatment in the autoclave did not significantly influence the parameter chroma $\left(C^{*}\right)$ in both species, except in radial direction of Sydney blue gum wood. On the other hand, hue angle (h) of rose gum and Sydney blue gum wood in radial and tangential directions was significantly influenced for both factors (steam pre-treatment and heating temperature) and its interaction, except in the tangential direction of Sydney blue gum wood.

The intensity of treatment necessary to significantly decrease chroma $\left(C^{*}\right)$ was distinct for rose gum and Sydney blue gum woods (Figure 3 ). In the radial direction, $C^{*}$ of rose gum wood showed significant decrease only after treatment 5 , while $C^{*}$ of Sydney blue gum wood showed significant decrease after treatment 4 . In the tangential direction, rose gum wood maintained the same behaviour observed in the radial direction, but Sydney blue gum wood presented a significant decrease after treatment 2.

Rose gum and Sydney blue gum wood showed similar reductions for hue angle $(h)$, which was approximately 14 and $18 \%$, respectively. Reduction of $h$ due to the thermal treatment represents a substitution of yellow tones to red tones. Tolvaj and Németh ${ }^{29}$ affirmed that hue angle varies between 0 and $90^{\circ}$, in which $0^{\circ}$ is related to red colour and $90^{\circ}$ is related to yellow colour. 
Table 3. Summary of factorial analysis of variance with additional treatment for the parameters $C^{*}$ and $h$ in radial and tangential direction of rose gum and Sydney blue gum wood.

\begin{tabular}{|c|c|c|c|c|c|}
\hline & & \multicolumn{4}{|c|}{ F-value } \\
\hline & & \multicolumn{2}{|c|}{ Radial } & \multicolumn{2}{|c|}{ Tangential } \\
\hline & & $C^{*}$ & $h$ & $C^{*}$ & $h$ \\
\hline \multirow[t]{4}{*}{ Rose gum } & Pre-treatment (A) & $58.17 *$ & $11195.42 *$ & $150.43 *$ & $4996.73 *$ \\
\hline & Temperature (B) & $9.43 *$ & $1030.36^{*}$ & $17.03 *$ & $431.43 *$ \\
\hline & A vs. B & $42.76^{*}$ & $38.45^{*}$ & $11.53 *$ & $42.03 *$ \\
\hline & Fact. vs. Control & $14.93 *$ & $5397.64 *$ & $144.74 *$ & $2624.01 *$ \\
\hline \multirow[t]{4}{*}{ S. blue gum } & Pre-treatment (A) & $327.71 *$ & $25408.79 *$ & $41.85^{*}$ & $7682.10 *$ \\
\hline & Temperature (B) & $39.40 *$ & $2185.79 *$ & $1.15^{\mathrm{ns}}$ & $575.57 *$ \\
\hline & A vs. B & $47.84 *$ & $52.16^{*}$ & $1.07^{\mathrm{ns}}$ & $164.80 *$ \\
\hline & Fact. vs. Control & $17.30^{*}$ & $15299.24 *$ & $239.24 *$ & $4701.23 *$ \\
\hline
\end{tabular}

*Significant at $1 \%$ of probability of error; ${ }^{\mathrm{ns}}=$ not significant; Fact= Factorial; Control= Control treatment (untreated samples).
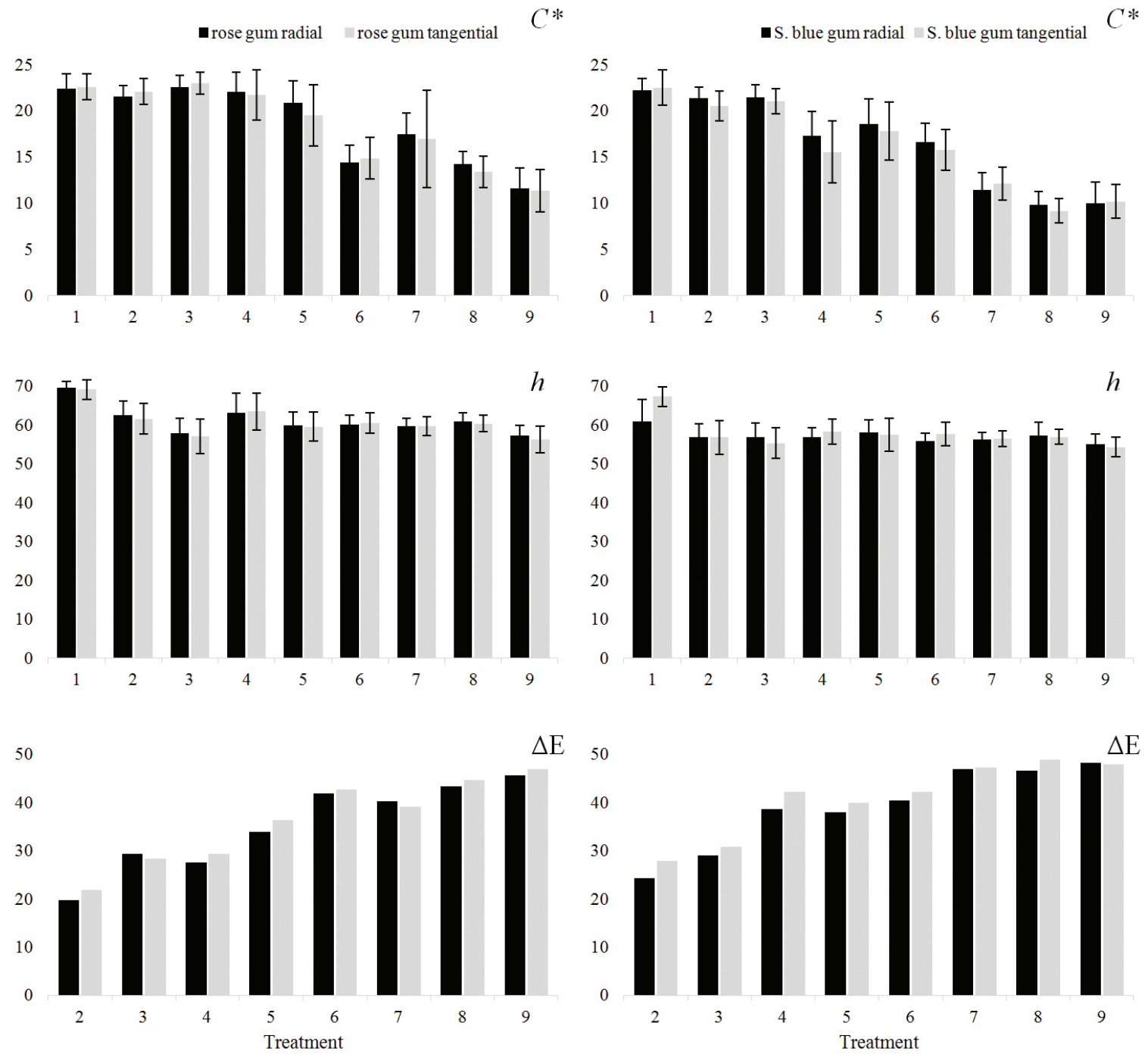

Figure 3. Average values of parameters $C^{*}, h$ and $\Delta \mathrm{E}$ in radial and tangential direction of rose gum and Sydney blue gum untreated and thermally treated wood. 

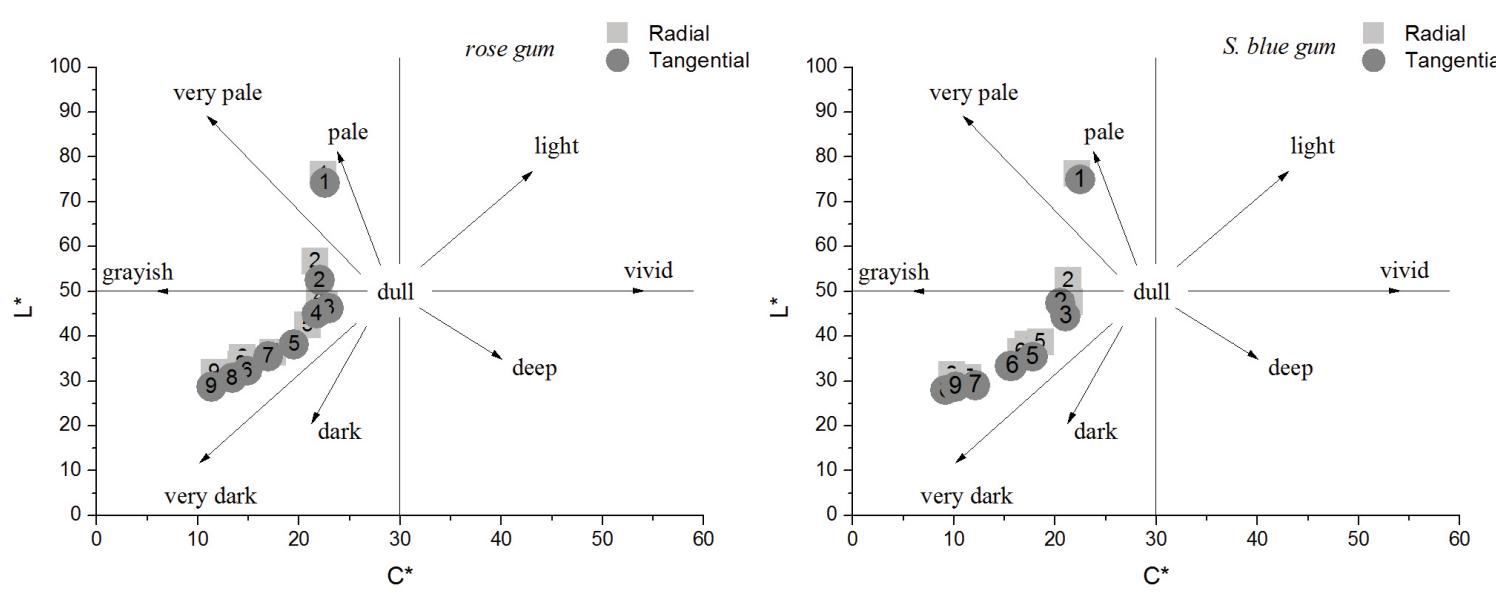

Figure 4. $L^{*}$ vs $C^{*}$ diagram for rose gum and Sydney blue gum untreated and thermally treated woods.

As expected, colour difference $(\Delta \mathrm{E})$ increased as a function of the heating temperature of treatment (Figure 3), which was previously identified in the visual analysis with darkened wood samples. The highest colorimetric differences between thermally treated samples and untreated samples were observed in treatments 8 and 9. That colour

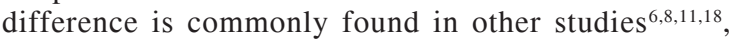
confirming that wood exposure at high temperatures causes desirable or undesirable significant colorimetric changes

As observed in Figure 4, $L^{*}$ vs. $C^{*}$ diagram for both species proves the aforementioned observations. Untreated wood of both species showed pale and very pale tones. Application of two-step steam-heat treatments caused a continuous migration of colour to dark and very dark tones and a greying of wood samples. Consequently, colour vivacity of wood samples decreased, which was clearly observed for the most drastic treatments (8 and 9).

\section{Conclusions}

Two-step steam-heat treatments were responsible for the gradual darkening of wood, in which the most drastic treatments presented the highest colorimetric changes.

In general, steam pre-treatment in the autoclave influenced the colorimetric parameters, especially lightness

\section{References}

1. Hill CAS. Wood modification: chemical, thermal and other processes. Chichester: John Wiley \& Sons; 2006. http://dx.doi. org/10.1002/0470021748

2. Esteves B, Velez Marques A, Domingos I and Pereira H. Heat-induced colour changes of pine (Pinus pinaster) and eucalypt (Eucalyptus globulus) wood. Wood Science and Technology. 2008; 42(5):369-384. http://dx.doi.org/10.1007/ s00226-007-0157-2

3. Poncsák S, Kocaefe D, Bouazara M and Pichette A. Effect of high temperature treatment on the mechanical properties of birch (Betula papyrifera). Wood Science and Technology. 2006; 40(8):647-663. http://dx.doi.org/10.1007/ s00226-006-0082-9

4. Ding T, Gu L and Liu X. Influence of steam pressure on chemical changes of heat-treated mongolian pine wood. BioResources. 2011; 6(2):1880-1889.
$\left(L^{*}\right)$ of rose gum wood thermally treated with lower temperatures, which favoured the visualisation of the effect of the autoclave as a steam pre-treatment.

Sydney blue gum wood was more susceptible to colorimetric modifications than rose gum wood, mainly in relation to the loss of lightness, which was the parameter that best described colour behaviour during thermal treatments.

Rose gum and Sydney blue gum presented a similar behaviour in all colorimetric parameters, which proves the efficiency of the CIE $L * a * b *$ technique.

Thermal treatment is interesting when the aim is aesthetic use due to the different tones obtained through the exposure of wood to high temperatures, which confirms the possibility of controlling the desired colour by applying process parameters.

\section{Acknowledgments}

The authors would like to thank CNPq (National Counsel of Technological and Scientific Development) and CAPES (Coordination for the Improvement of Higher Level Personnel) for supporting this work.
5. Todaro L, Dichicco P, Moretti N and D'auria M. Effect of combined steam and heat treatments on extractives and lignin in sapwood and heartwood of Turkey oak (Quercus cerris L.) wood. BioResources. 2013; 8(2):1718-1730.

6. Todorovic N, Popovic Z, Milic G and Popadic R. Estimation of heat-treated beechwood properties by color change. BioResources. 2012; 7(1):799-815.

7. Akgül M and Korkut S. The effect of heat treatment on some chemical properties and colour in Scots pine and Uludağ fir wood. International Journal of Physical Sciences. 2012; 7(21):2854-2859.

8. Bekhta P and Niemz P. Effect of high temperature on the change in color, dimensional stability and mechanical properties of spruce wood. Holzforschung. 2003; 57(5):539546. http://dx.doi.org/10.1515/HF.2003.080

9. Oliveira RMD, Brisolari A, Sales A and Gonçalves D. Wettability, Shrinkage and color changes of Araucaria angustifolia after 
heating treatment. Materials Research. 2010; 13(3):351-354. http://dx.doi.org/10.1590/S1516-14392010000300012

10. Hu C, Jiang G, Xiao M, Zhou J and Yi Z. Effects of heat treatment on water-soluble extractives and color changes of merbau heartwood. Journal of Wood Science. 2012; 58(5):465469. http://dx.doi.org/10.1007/s10086-012-1265-7

11. Cademartori PHG, Schneid E, Gatto DA, Stangerlin DM and Beltrame R. Thermal modification of Eucalyptus grandis wood: variation of colorimetric parameters. Maderas: Ciencia y Tecnolgía. 2013; 15(1):57-64.

12. Wallis NK. Australian timber handbook. London: Angus and Robertson; 1970.

13. Rosu D, Teaca C-A, Bodirlau R and Rosu L. FTIR and color change of the modified wood as a result of artificial light irradiation. Journal of Photochemistry and Photobiology B: Biology. 2010; 99(3):144-149. PMid:20392648. http://dx.doi. org/10.1016/j.jphotobiol.2010.03.010

14. Konica Minolta. Precise color communication: color control from perception to instrumentation. Japan: Konica Minolta Sensing Inc; 2007.

15. Mattos BD, Cademartori PHG, Lourençon TV and Gatto DA. Colour changes of Brazilian eucalypts wood by natural weathering. International Wood Products Journal. 2014; 5(1):33-38. http://dx.doi.org/10.1179/204264 5313Y.0000000035

16. Cao Y, Chan F, Chui Y-H and Xiao H. Characterization of flax fibres modified by alkaline, enzyme, and steam-heat treatments. BioResources. 2012; 7(3):4109-4121.

17. McDonald AG, Fernandez M, Kreber B and Laytner F. The chemical nature of kiln brown stain in radiata pine. Holzforschung. 2005; 54(1):12-22.

18. Unsal O, Korkut S and Atik C. The effect of heat treatment on some properties and colour in eucalyptus (Eucalyptus camaldulensis Dehn.). Maderas: Ciencia y Tecnología. 2003; 5(2):145-152.

19. Esteves B, Marques A, Domingos I and Pereira H. Influence of steam heating on the properties of pine (Pinus pinaster) and eucalypt (Eucalyptus globulus) wood. Wood Science and
Technology. 2007; 41(3):193-207. http://dx.doi.org/10.1007/ s00226-006-0099-0

20. Moura LF and Brito JO. Effect of thermal rectification on colorimetric properties of Eucalyptus grandis and Pinus caribaea var. hondurensis woods. Scientia Forestalis. 2011; 39(89):69-76.

21. Mitsui K, Takada H, Sugiyama M and Hasegawa R. Changes in the properties of light-irradiated wood with heat treatment. Part 1: Effect of treatment conditions on the change in color. Holzforschung. 2004; 55(6):601-605.

22. Bourgois J, Guyonnet R and Janin G. La mesure de couleur: une méthode d'étude et d'optimisation des transformations chimiques du bois thermolysé. Holzforschung. 1991; 45(5):377382. http://dx.doi.org/10.1515/hfsg.1991.45.5.377

23. Sundqvist B. Wood color control during kiln-drying. Forest Products Journal. 2002; 52(2):30-37.

24. Wiberg P. Colour changes of Scots pine and Norway spruce. Holz als Roh- und Werkstoff. 1996; 54(5):349-354. http:// dx.doi.org/10.1007/s001070050199

25. Mori CLSO, Mori FA, Lima JT, Trugilho PF and Oliveira AC. Influência das características tecnológicas na cor da madeira de eucaliptos. Ciência Florestal. 2004; 14(2):123-132.

26. Chen Y, Fan Y, Gao J and Stark NM. The effect of heat treatment on the chemical and color change of black locust (Robinia pseudocacia) wood flour. BioResources. 2012; 7(1):11571170.

27. Varga D and Van der Zee ME. Influence of steaming on selected wood properties of four hardwood species. Holz als Roh- und Werkstoff. 2008; 66(1):11-18. http://dx.doi.org/10.1007/ s00107-007-0205-5

28. Schnabel T, Zimmer B and Petutschnigg A. On the modelling of colour changes of wood surfaces. European Journal of Wood and Wood Products. 2009; 67(2):141-149. http://dx.doi. org/10.1007/s00107-008-0293-x

29. Tolvaj L and Németh K. Correlation between hue-angle and colour lightness of steamed black locust wood. Acta Silvatica \& Lignaria Hungarica. 2008; 4:55-59. 